\author{
Tvrtko Prćić \\ University of Novi Sad \\ Faculty of Philosophy \\ Novi Sad, Serbia
}

\title{
DISTINCTIVE PROPERTIES OF ENGLISH LEXICAL AFFIXES: AN OVERALL VIEW**
}

\begin{abstract}
This paper deals with determining distinctive properties of English lexical affixes, i.e. derivational prefixes, like un-, in untie, and suffixes, like -ish, in childish. Its main aim is to establish a set of synchronically relevant affixal properties that will make it possible, firstly, to offer a characterization of all affixes and, secondly, to ensure their appropriate lexicological, lexicographic and pedagogical treatment. The discussion will be organized in the following way: in Section 1, some scenesetting remarks will be made; in Section 2, theoretical explanations regarding the nature and status of affixes will be given; in Section 3, two sets of properties, essential and relational, stemming from prefixal and suffixal forms, functions, meanings and uses, will be identified, described and illustrated; and in Section 4, a summary of the main results of the paper alongside their possible implications will be offered.
\end{abstract}

Key words: affixes, lexical, prefixes, suffixes, derivational, English, distinctive properties

\footnotetext{
E-mail address: tvrtko.prcic@gmail.com

** To Professor Hlebec, an unassuming, meticulous and highly original scholar, from whom I have learnt a lot. This paper is part of the research on Project No. 178002, entitled Languages and Cultures in Time and Space, which is financially supported by the Ministry of Education, Science and Technological Development of the Republic of Serbia.
} 


\section{Opening remarks}

In this paper an attempt will be made to catalogue the entire set of distinctive properties of English lexical affixes, so as to provide an overall view of the properties that determine the unique identity of each individual lexical affix in English and, at the same time, their interrelations with other affixes. The determination of distinctive affixal properties takes into account all levels of linguistic analysis as well as the paradigmatic and syntagmatic axes of relationships between linguistic units. In this way, an identity card, as it were, of every affix can be put together, allowing insights not only into single affixes but also into networks of several, mutually linked, affixes, when such networks exist.

The model to be proposed is intended to achieve three principal objectives: firstly, from a lexicological angle, to help build up a descriptively complete picture of all lexical affixes in English and, mutatis mutandis, other comparable languages; secondly, from a lexicographic angle, to help draw up a blueprint for the representation of affixes in dictionaries, generalpurpose and, more importantly, specialized ones, devoted to affixes; and thirdly, from a pedagogical angle, to help teach lexical affixes to students, especially EFL university students.

The discussion will be organized into three sections, as follows: in Section 2, theoretical concepts regarding the nature and status of English lexical affixes will be defined; two types of distinctive affixal properties, essential and relational, will be introduced, elaborated and exemplified in Section 3; and in Section 4, after an overview of the main results of the paper, possible implications of the proposal presented herein will be briefly assessed.

\section{Theoretical considerations}

The theoretical groundwork espoused here is the Marchandean signoriented approach to word formation (Marchand 1969, originally 1960), with its roots in Saussurean structuralism (de Saussure 1916), whereby the morpheme is conceived as a triad of form, content and function. Hence, the status of affix is accorded only to those phoneme sequences which are fully-fledged morphemes in present-day English, in that a particular phonological form is systematically associated with at least 
one particular content and one particular function, irrespective of the affix's origin; for example, re- in rewrite is a prefix, but not in the synchronically monomorphemic receive, and -ness in happiness is a suffix, but not in the synchronically monomorphemic harness. The term 'affix' will be used as a superordinate for the terms 'prefix' and 'suffix', to refer to bound elements like re- and -ness, respectively. In its prototypical manifestation, an affix has the following features (cf. Warren 1990): it is a bound lexical closed-set morpheme, which attaches to the beginning of a free - simple, complex or compound - base (when prefix) or to the end of a free base (when suffix), in order to formally and semantically modify that base and which in the process displays a greater or less degree of productivity.

In addition and in contradistinction to the more or less closed set of affixes, the English lexicon also contains an open, and expanding, set of combining forms - initial, like morpho- and jazzo- (known as initial combining forms, or ICFs), and final, like -logy and -phile (known as final combining forms, or FCFs), which, between them, create words like morpho+ -logy > morphology and jazzo- + -phile > jazzophile. Even though ICFs and FCFs are bound morphs and hence resemble prefixes and suffixes, they, unlike affixes, have full lexical meaning and hence resemble bases; also unlike prefixes and suffixes, ICFs and FCFs can cooccur in words, and, lastly, they display productivity in a significantly different way from affixes. As can be inferred from this short comparison, combining forms and affixes, in spite of appearing at first sight similar (so much so that they are treated as one broad category, particularly in some authoritative and highly respected general-purpose and specialized dictionaries of English, the titles of which will purposely not be revealed), they are markedly dissimilar in certain key respects. This calls for establishing a different set of distinctive properties for combining forms, which will adequately reflect their individuality and bring out clearly the similarities and differences between themselves and affixes (for more detailed accounts of combining forms, their types and distinctive properties, in comparison with those of affixes, see Bauer 1983; Bauer and Huddleston 2002; Lalić Krstin 2016; Prćić 2005, 2008; Quirk, et al. 1985, and the references therein). Because constituting distinct categories, albeit both delimited by fuzzy borders, that at the edges touch and sometimes even overlap with each other, combining forms lie beyond the scope of the present paper, whose focus remains on affixes (as systematically distinguished from combining forms and inventoried in Prćić 2005, 2008). 
To round off setting the theoretical scene, two observations concerning the nature of affixes need yet to be made (cf. Prćić 1999a). Firstly, affixes have a contributory role in word formation and hence affixal properties should be construed mainly in terms of what they contribute graphologically, phonologically, morphosyntactically, semantically and stylistically to the properties of the base, in deriving a (new) morphologically complex word - either a prefixation or a suffixation. Concrete contributions can be ascertained by answering the two complementary questions in this example: what does the suffix -ship specifically contribute to the base friend in the word friendship and, as a result, what specific modifications does the base friend undergo through the agency of the suffix -ship in the word friendship?

Secondly, affixal properties represent a systematic and predictable contribution in form, content and function to any eligible base. Concrete contributions are considered word-independent, because the same set of modifications are involved in all words derived from a class of bases - and this only on condition that such words are compositional formations, i.e. morphologically and semantically analysable, and, for this reason, predictable; for example, the prefix re-, in the sense 'again', in words like readjust, reappear, re-elect, reread, revisit. However, in words going through, or having gone through, the process of idiomatization, certain gradual changes in form and/or content may in time take place, or have already taken place, within words as wholes. All such in-word modifications, pertaining to alterations of original properties of both affixes and bases, are non-systematic and unpredictable, and therefore are considered word-dependent, because they have developed uniquely within particular words and do not exist outside them; for example, the prefix re-, 'again', in the idiomatization rewrite, which means 'write again in a better way' and not purely 'write again'. Due to the working of idiomatization, the morphological and semantic analysability of words affected in this way progressively decrease, their compositionality is blurring and their predictability is lessening (for more extensive accounts of idiomatization, or lexicalization, as it is also known, see Bauer 1983; Bauer and Huddleston 2002; Hohenhaus 2005; Lieber and Štekauer 2014; Lipka 2002; Prćić 2001, 2016; Quirk, et al. 1985).

In accordance with the import of these two observations, a wellfounded description of affixal properties should clearly reflect their contributory role and their systematic contribution to the base, and leave the effects of idiomatization to the description of individual words. 


\section{A survey of distinctive properties of English affixes}

Distinctive properties of any lexical unit, affixes included, define that unit's identity, its place in the lexicon and its relationship with other comparable lexical units in that lexicon. In attempting to fully catalogue affixal distinctive properties, provision must first be made for individual formand content-based behavioural traits of an affix - this set of properties will be called here 'essential properties'; a second, supplementary, set of properties, called here 'relational properties', takes into consideration paradigmatic and syntagmatic relations between individual affixes.

The two sets of distinctive properties of English affixes will be discussed and exemplified in the coming subsections.

\subsection{Essential properties}

Essential properties are inherent to all affixes, i.e. prefixes and suffixes, they comprise the identifying features of an affix in isolation, its contribution to a base, or a class of bases, and reflect the affix's individuality. Involved in determining the nature of these properties are all levels of linguistic analysis, viz. graphology, phonology, morphosyntax, semantics and stylistics, which yield six essential properties altogether (their account here draws in part on the argumentation in Prćić 1999a).

(1) Spelling - in the domain of graphology / orthography, this property captures the realization of an affix in writing. What the affix contributes graphologically to bases consists in the letter-and-mark sequence that represents it in isolation (e.g. -ship) and within words (friendship); and also, where applicable, variants of the sequence (-ize/-ise), orthographic changes to the base, like dropping of a silent final $-e$ before a suffix ( $\operatorname{driv}[e]+-e r>$ driver), or vacillation between dropping and non-dropping of a silent final $-e$ before a suffix (lov[e] $+-a b l e>$ lovable vs love $+-a b l e>$ loveable), or indication of prefix/ base hyphenation to distinguish an unanalysable homograph from an analysable one (recover vs re-cover).

(2) Pronunciation - in the domain of phonology, this property captures the realization of an affix in speech. What the affix contributes phonologically to bases consists in the sound sequence that represents it in isolation (e.g. / $\mathrm{Jip} /$ ) and within words (/'frend $\int \mathrm{Ip} /$ ); and also, mostly concerning suffixes, the influence 
of the affix on the stress pattern of the word (cf. Jones 2006; Wells 2008), which may either remain unchanged, with stressneutral suffixes (-ship: /(')frend > frend/rp/), or it may shift, with stress-imposing suffixes, either by falling on the suffix itself (-ese: /dzə'pæn > dzæpə'ni:z/), or on the penultimate syllable (-ic: /'ætəm $>$ o'tomik/), or on the antepenultimate syllable (-ity: / kri'ertıv > ,krier'trviti/).

(3) Attachability - in the domains of morphosyntax and semantics, this property captures the ability of an affix to attach to a base, or a class of bases, of a certain part of speech, and to derive words of a certain part of speech (cf. Bauer 1983; Bauer and Huddleston 2002; Quirk, et al. 1985). What the affix contributes morphosyntactically to bases consists in the actual part of speech of the derived word, which may be either the same as that of the base, with classmaintaining affixes (e.g. dis- + connect $_{\mathrm{v}}>$ disconnect $_{\mathrm{v}}$ ), or different from that of the base, with class-changing affixes (develop $p_{\mathrm{v}}+-$-ment $>$ development $t_{\mathrm{n}}$ ); and also, where necessary, subcategorizations of the base, mostly semantically and/or pragmatically conditioned, like transitivity of verbal bases to which the suffix -able, in the sense 'that can be', typically attaches $\left(w^{2} h_{\mathrm{v} / \mathrm{tr}}+-a b l e\right)$.

(4) Meaning - in the domain of semantics, this property captures the descriptive meaning of an affix (cf. Prćić 2016). What the affix contributes semantically to bases consists in a small set of diagnostic features, specified within a brief definition, wellbalanced between generality and specificity (e.g. re- means 'again, repetition', as in reread; -ish means 'around, approximately', as in sixish); and also, where applicable, an indication of synonymy and antonymy of affixes (cf. Cruse 2010; Murphy 2003; Prćić 2016), in appropriately worded comparable definitions (synonymy: -er, 'agent', as in producer vs -or, 'agent', as in director; antonymy: hyper-, 'above normal', as in hypertension vs hypo-, 'below normal', as in hypotension).

(5) Associative Meaning - in the domain of stylistics, this property captures the associative meaning of an affix (cf. Prćić 2016). What the affix contributes stylistically to bases, where applicable, consists in restrictions on the word's range of application and includes, most notably, dialect (e.g. -ize, as in modernize: worldwide English vs -ise, as in modernise: British English), register (-ide, 
as in chloride: chemistry), formality (-er, in adviser: neutral vs -or, in advisor: formal).

(6) Productivity - in the domains of morphosyntax and semantics, this property captures the ability of an affix to be synchronically used in the derivation of new words (cf. Bauer 1983, 2001; Bauer, Lieber and Plag 2014; Kastovsky 1986; Lieber and Štekauer 2014; Plag 1999; Prćić 1999b). What the affix contributes to bases in this respect consists in its relative position on a three-zone scale of productivity, spanning high $\leftrightarrow$ restricted $\leftrightarrow$ low degrees, with affixes in the high zone having greater likelihood of being chosen as input units for new words (e.g. -er deriving agent and/or instrument nouns from dynamic verbs, like play $_{\mathrm{v}}+-e r>$ player $_{\mathrm{n}}$ : high productivity; -th deriving abstract nouns from adjectives, like warm $_{\text {adj }}+$-th $>$ warmth $_{\mathrm{n}}$ : low productivity).

When the affix under scrutiny is polyfunctional, in that several distinct functions and related or unrelated meanings are associated with a single form, as is the case with the prefix un- in the words unhappy, unrest, untie, unsaddle, and with the suffix -ish in the words childish, yellowish, fiftyish, Finnish, properties (3)-(6) need to be specified for each function separately.

\subsection{Relational properties}

Unlike essential properties, which are evident in all affixes, relational properties manifest themselves only in some prefixes and suffixes, only when certain content- and/or form-based conditions are met, they comprise the interacting features of an affix with another or others, and reflect the affix's companionability. Involved in determining the nature of these properties are paradigmatic and syntagmatic relations established, or establishable, between affixes.

In paradigmatic relations, the focus is on interaffixal sense relations, which yield two relational properties.

(7) Interaffixal Synonymy - in the domains of semantics and pragmatics, this property captures the fact that at least two affixes share the same descriptive meanings and morphosyntactic functions, and, as a result, are liable to derive synonymous words when attached to the same base (e.g. -er, -or, -ant, -ee, in cohabiter, cohabitor, cohabitant, cohabitee) and hence to enter into rivalry 
(or, competition) in the process of derivation of new words (cf. Bauer, Lieber and Plag 2014; Kastovsky 1982, 1986; Prćić 1999b). The relationship of this kind develops either between prefixes (e.g. un-, in undress, de-, in destabilize, and dis-, in disconnect, all three of them in the sense 'to reverse'), or between suffixes (e.g. -ness, in happiness, -ity, in curiosity, -th, in width, all three of them in the sense 'state of'), or between prefixes and suffixes (e.g. the prefix en-, in enlarge, and the suffixes -ize, in normalize, -ify, in purify and -en, in widen, all four of them in the sense 'to make').

(8) Interaffixal Antonymy - in the domains of semantics and pragmatics, this property captures the fact that two affixes have opposite descriptive meanings but the same functions, and, as a result, are liable to derive antonymous words when attached to the same base. The relationship of this kind develops mostly between prefixes (e.g. over- and under-, in overcook and undercook, in the sense 'more than necessary' and 'less than necessary', respectively), and, less often, between suffixes (e.g. -er and -ee, in interviewer and interviewee, in the sense 'agent' and 'patient', respectively).

It may be as well to point out here that the relations of both interaffixal synonymy and antonymy, just as ordinary lexical sense relations, exist exclusively between individual meanings (and functions) of affixes and not across the whole spectrum of meanings; for example, the prefix un-, in undress, is synonymous with de-, in destabilize, and dis-, in disconnect, only when it means 'to reverse', but when it means 'not', in unhappy, it is synonymous with in-, in inexpensive, dis-, in dissimilar, non-, in nonaddictive, and $a-$, in atypical.

In syntagmatic relations, on the other hand, the focus is on interaffixal preferences, which also yield two relational properties.

(9) Cooccurrencing - in the domains of morphosyntax and semantics, this property captures the fact that two affixes systematically cooccur in words, because an affix tends to attract another affix in derived words (cf. Bauer, Lieber and Plag 2014). The relationship of this kind develops in two ways: firstly, mostly between suffixes (e.g. to derive an action noun, the suffix -ation is typically attracted by the suffixes -ize, as in industrialization, -ify, as in purification, and -ate, as in hyphenation; in the latter case, -ation overlaps with -ate), with some suffixes attracting at least two synonymous suffixes, hence open to rivalry (e.g. the nominal 
suffixes -ness and -ity, of varying degrees of frequency, are both attracted by some adjectival bases in -al, as in grammaticalness and grammaticality).

And secondly, this relationship develops between suffixes and prefixes (e.g. to derive a negative adjective, the prefix un- is typically attracted by the suffix-able, as in uneatable, whereas the prefix in-is typically attracted by the suffix -ible, as in inaccessible), with some suffixes attracting at least two synonymous prefixes, hence also open to rivalry (e.g. the negative adjectival prefixes un- and $a$-, of varying degrees of frequency, are both attracted by some adjectival bases in -al, as in untypical and atypical). Moreover, this relationship is recursive in nature, especially with certain sets of cooccurring suffixes, among which intersuffixal chain attraction has developed, as in developmentally, with three suffixes, and organizationally, with four suffixes.

(10) Correlationing - in the domain of morphosyntax and semantics, this property captures the fact that two affixes systematically correlate in words, because an affix tends to regularly replace another affix in derived words. The relationship of this kind develops between suffixes (e.g. to derive a human noun, the suffix -ism, in the sense of 'a system of theory, methodology or practice' is replaced with the suffix -ist, in the sense of 'an adherent of a system of theory, methodology or practice', as in structural[ism] > structuralist; in some cases, -ism, or -ist, is replaced with the suffix -ize, in the sense of 'to follow a system of theory, methodology or practice', to derive an action verb, as in terror [ism] / terror[ist] > terrorize).

Some suffixes can be replaced with two synonymous suffixes, hence open to rivalry (e.g. the nominal suffixes -ance and -ancy, and -ence and -ency, of varying degrees of frequency, can replace the -ant and -ent in some adjectival bases, as in elegant > elegance, elegancy and corpulent > corpulence, corpulency), with some suffixes replaced by their bound allomorphs before a new derivation takes place (e.g. the adjectival suffixes -able and -ible are replaced by their bound allomorphs before the nominal suffix -ity attaches, as in desirable: desirabil- + -ity > desirability and flexible: flexibil- + -ity $>$ flexibility).

Once again at this place, it will be reiterated that with polyfunctional affixes, where several distinct functions and related or unrelated meanings coincide in a single form, properties (7)-(10), where applicable, need to be specified for each function separately. 


\section{Summing up and looking ahead}

In this paper, a model has been put forward with the intention of affording an overall view of distinctive properties of English lexical affixes. Distinctive properties have been organized around two sets: the one, inherent to all affixes and reflecting their individuality, contains essential properties and comprises Spelling, Pronunciation, Attachability, Meaning, Associative Meaning and Productivity; and the other set, manifest only in some affixes and reflecting their companionability, contains relational properties and comprises Interaffixal Synonymy, Interaffixal Antonymy, Cooccurrencing and Correlationing. By providing all the required elements for each affix's identity card and thus helping to build up a descriptively complete picture of all lexical affixes in English and, mutatis mutandis, other comparable languages, the first, lexicological, principal objective of the three stated in the introduction, has hopefully been fulfilled.

Closely connected with this one is the second, lexicographically relevant, objective - helping to draw up a blueprint for the representation of affixes in dictionaries, general-purpose and, more importantly, specialized ones, devoted to affixes. By and large, in the treatment of affixes in generalpurpose dictionaries, there is ample room for improvement, both in terms of the quality and quantity of the information included. More specifically, as demonstrated in a critical assessment of the system of coverage of two prefixes, dis- and pro-, and two suffixes, -ish and -or, in the then current, 1995, editions of four English pedagogical dictionaries - Oxford Advanced Learner's Dictionary of Current English, Longman Dictionary of Contemporary English, Collins COBUILD English Dictionary, and Cambridge International Dictionary of English, inconsistencies are found in presenting information on affixes, as no firm system for dealing with either affixal forms or meanings is discernible (cf. Prćić 1999a). The properties provided are almost invariably essentials, whereas relationals are quite a rarity and only in the shape of paradigmatic relations. Twenty years after this analysis, a new look into the now current editions of the 'big four', joined, in the meantime, by the 'fabulous fifth', Macmillan English Dictionary for Advanced Learners, surprisingly enough, shows hardly any emendations. The conclusion reached two decades ago, that "the 'big four', on the whole, portray affixes as nothing more than poor relations of words and phrases" (Prćić 1999a: 274), sadly remains valid today - and for no apparent reason. 
Affixes are much less poor relations in specialized dictionaries devoted to English lexical affixes and their properties, notably the following: Ologies and Isms. A Dictionary of Word Beginnings and Endings (Quinion 2002), Affixes. The Building Blocks of English (Quinion 2008), Word Parts Dictionary. Standard and Reverse Listings of Prefixes, Suffixes, and Combining Forms (Sheehan 2000), Collins COBUILD English Guides 2: Word Formation (Sinclair 1991) and A Dictionary of English Affixes. Their Function and Meaning (Stein 2007). With their strengths and weaknesses, each of these is a usable and reliable guide to affixal properties. Unfortunately, here again, in some there are inconsistencies in presentation and/or shortcomings in organization, especially in the choice of properties and the manner in which they are described. A much-needed comparative analysis of the theory, methodology and practice behind this quintet of dictionaries would warrant a separate critical review, incorporating a yes, a qualified yes and a no recommendation for EFL students' use.

And finally, the third of the objectives formulated earlier is pedagogically oriented in that it is about helping to teach lexical affixes to EFL university students. Tailored primarily for courses in lexical morphology and/or word formation, a new method for handling efficiently the systems of English lexical prefixes and suffixes needs to be worked out. It would have to build around three key components: firstly, the affixal identity card approach, presented above, as a target entity; secondly, the available dictionaries of affixes, mentioned above, as a (re)source entity; and thirdly, the compensatory materials and activities designed to narrow, if not to bridge, the delicate gap between the requirements of the target entity and the provisions of the (re)source entities. However, the topic of 'interim measures' and their implementation, despite its significance, is outside the scope of the present paper and it definitely calls for, and merits, further exploration and elaboration in a separate research paper.

\section{References}

Bauer, L. (1983). English Word-Formation. Cambridge: Cambridge University Press. Bauer, L. (2001). Morphological Productivity. Cambridge: Cambridge University Press.

Bauer, L. and R. Huddleston (2002). Lexical Word Formation. In: R. Huddleston and G. K. Pullum (eds.), The Cambridge Grammar of the English Language, Cambridge: Cambridge University Press, 1621-1721. 
Bauer, L., R. Lieber and I. Plag (eds.) (2014). The Oxford Reference Guide to English Morphology. Oxford: Oxford University Press.

Cruse, A. (2010). Meaning in Language. An Introduction to Semantics and Pragmatics. $3^{\text {rd }}$ edition. Oxford: Oxford University Press.

Hohenhaus, P. (2005). Lexicalisation and Institutionalisation. In: P. Štekauer and R. Lieber (eds.), Handbook of English Word-Formation, Dordrecht: Springer, 353-373.

Jones, D. (2006). Cambridge English Pronouncing Dictionary, edited by P. Roach, J. Hartman and J. Setter. $17^{\text {th }}$ edition. Cambridge: Cambridge University Press.

Kastovsky, D. (1982). Word-Formation: a Functional View. Folia Linguistica, 16, 181-198.

Kastovsky, D. (1986). The Problem of Productivity in Word Formation. Linguistics, 24, 585-600.

Lalić Krstin, G. (2016). Morfemizacija krnjih leksičkih osnova u savremenom engleskom jeziku. Leksikološki i leksikografski aspekti [Morphemization of Truncated Lexical Bases in Present-Day English. Lexicological and Lexicographic Aspects]. PhD dissertation. Faculty of Philosophy, University of Novi Sad.

Lieber, R. and P. Štekauer (eds.). (2014). The Oxford Handbook of Derivational Morphology. Oxford: Oxford University Press.

Lipka, L. (2002). English Lexicology. Lexical Structure, Word Semantics, and Word-Formation. $3^{\text {rd }}$ edition. Tübingen: Gunter Narr.

Marchand, H. (1969). The Categories and Types of Present-Day English WordFormation. $2^{\text {nd }}$, completely revised and enlarged edition. München: C. H. Beck'sche Verlagsbuchhandlung.

Murphy, M. L. (2003). Semantic Relations and the Lexicon. Antonymy, Synonymy, and Other Paradigms. Cambridge: Cambridge University Press.

Plag, I. (1999). Morphological Productivity. Structural Constraints in English Derivation. Berlin/New York: Mouton de Gruyter.

Prćić, T. (1999a). The Treatment of Affixes in the 'Big Four' EFL Dictionaries. International Journal of Lexicography, 12/4, 263-279.

Prćić, T. (1999b). Productivity of Competing Affixes: the Case of Agentive Suffixes in English. Linguistica e Filologia, 9, 125-134.

Prćić, T. (2001). Interpreting Morphologically Complex Lexemes Revisited. In: E. Németh T. and K. Bibok (eds.), Pragmatics and the Flexibility of Word Meaning, Oxford: Elsevier, 225-244. 
Prćić, T. (2005). Prefixes vs Initial Combining Forms in English: a Lexicographic Perspective. International Journal of Lexicography, 18/3, $313-334$.

Prćić, T. (2008). Suffixes vs Final Combining Forms in English: a Lexicographic Perspective. International Journal of Lexicography, 21/1, $1-22$.

Prćić, T. (2016). Semantika i pragmatika reči. 3., elektronsko, izdanje [Semantics and Pragmatics of the Word. $3^{\text {rd }}$, digital, edition]. Novi Sad: Filozofski fakultet. (30 January 2019) < http://digitalna.ff.uns.ac.rs/ sadrzaj/2016/978-86-6065-356-9>.

Quinion, M. (2002). Ologies and Isms. A Dictionary of Word Beginnings and Endings. Oxford: Oxford University Press.

Quinion, M. (2008). Affixes. The Building Blocks of English. (30 January 2019) < http://www.affixes.org/> .

Quirk, R., et al. (1985). A Comprehensive Grammar of the English Language. London/New York: Longman.

Saussure, F. de (1916). Cours de linguistique générale. Paris: Payot.

Sheehan, M. J. (2000). Word Parts Dictionary. Standard and Reverse Listings of Prefixes, Suffixes, and Combining Forms. Jefferson/London: McFarland.

Sinclair, J. (ed.) (1991). Collins COBUILD English Guides 2: Word Formation. London: HarperCollins Publishers.

Stein, G. (2007). A Dictionary of English Affixes. Their Function and Meaning. Munich: Lincom Europa.

Warren, B. (1990). The Importance of Combining Forms. In: W. U. Dressler, et al. (eds.), Contemporary Morphology, Berlin/New York: Mouton de Gruyter, 111-132.

Wells, J. C. (2008). Longman Pronunciation Dictionary. $3^{\text {rd }}$ edition. Harlow: Pearson Education.

Received: 4 March 2019

Accepted for publication: 4 April 2019 
Твртко Прћић

\section{ДИСТИНКТИВНА СВОЈСТВА ЕНГЛЕСКИХ ЛЕКСИЧКИХ АФИКСА: ЈЕДАН СВЕОБУХВАТАН ПОГЛЕД}

\section{Сажетак}

Овај рад бави се одређивањем дистинктивних својстава енглеских лексичких афикса, тј. деривационих префикса, попут un-, у untie [= одвезати, развезати], и суфикса, попут -ish, у childish [= deтuњacm]. Његов главни циљ јесте да се успостави скуп синхроно релевантних афиксалних својстава која ће омогућити, прво, да се изврши карактеризација свих афикса и, друго, да се обезбеди њихова примерена лексиколошка, лексикографска и педагошка обрада. Расправа је организована на следећи начин: у Одељку 1 дато је неколико уводних напомена; у Одељку 2 пружена су теоријска објашњења у вези с природом и статусом афикса̂; у Одељку 3 наведена су, описана и илустрована два скупа својстава, основних и односних, која проистичу из форми, функција, значења и употреба префикса̂ и суфикса̂; и у Одељку 4 понуђен је кратак преглед најважнијих резултата овог рада заједно с њиховим могућим импликацијама.

Кључне речи: афикси, лексички, префикси, суфикси, деривациони, енглески језик, дистинктивна својства 